\title{
Government innovation: The challenges and the best practice of smart city in Indonesia
}

\author{
Haidar Fikri \\ Public Administration Department \\ Faculty of Social Studies and Politics \\ Sebelas Maret University \\ Surakarta, Indonesia
}

\author{
Didik G. Suharto \\ Public Administration Department \\ Faculty of Social Studies and Politics \\ Sebelas Maret University \\ Surakarta, Indonesia \\ Rino Ardhian Nugroho \\ Public Administration Department \\ Faculty of Social Studies and Politics \\ Sebelas Maret University \\ Surakarta, Indonesia
}

\begin{abstract}
Nowadays, the concept of city building by putting forward the smart city is mostly discussed by the Indonesian government. The discussion and ideas are from the assessment of government on the idea capability in building smart city to solve the problems in the city such as traffic jam, safety, and garbage. The building of smart city with the use of technology and information is expected to be a solution in serving the society. It is also aimed to be a solution for the problems in the region. Literally, smart city is meant as "kota cerdas".Smart city is designed to help the residents' activity especially in managing the resources efficiently. It also gives the easy to access the information to the society and to anticipate the unexpected events. BAPPENAS has decided the road map of city building in Medium-Term Development Plan (RPJMN) in 2015-2019. There has been the development of 7 metropolitan areas, 5 new metropolitan areas, 10 new public cities, 20 autonomous cities and 39 new developing centrals. In 2017, the government selected 25 cities/ regencies to develop smart city. It is also expected that the number will add in 2018. Ministry of communication and information targets 75 cities/ regencies to develop smart city through “Gerakan Menuju 100 Smart City" which means a movement for 100 smart cities. The success of smart city in Indonesia has become a big attention. Therefore, the research on smart city becomes an interesting thing. The success of smart city is related to the obstacles and the challenges. The best practice on smart city becomes the best learning for academicians and Indonesian bureaucracy. This research used descriptivequalitative approach. The result of the research explains the obstacles and the challenges of the smart city implementation in Indonesia. The best practice of smart city is also supposed as a pilot project and reference for other areas that have not implemented smart city.
\end{abstract}

Keywords-smart city; government innovation; bureaucracy; effectiveness; efficiency

\section{INTRODUCTION}

In implementing regional government based on the basic law of republic of Indonesia 1945, regional government which manages their own governance with autonomy principle is directed to accelerate the prosperity of society through upgrading, service, empowerment and participation of society, and the increase of regional competition by paying attention to the principle of democracy, equal distribution, justice, peculiarity of a region in the system of unitary state of the republic of Indonesia. The implementation of regional autonomy or decentralization brings a challenge for regional government in giving the service to responsive society. It presents that decentralization is an authority submission by the central government to regional government through the framework of state system in taking the decision [1, p. 86]. It is same as the definition of decentralization based on the law number 23 of 2014 about regional government. It explains that the submission of government authority by the government to autonomy region is to manage the governmental affair in the system of unitary state of the republic of Indonesia. Regional government is responsible to conduct the compulsory affair mentioned in the law number 23 of 2014 in paragraph 11 about regional government. It states that regional authority consists of two, compulsory and choice government affairs. Compulsory affair relates to public service. Meanwhile, choice affair of regency government relates to the real and potential affair to improve the prosperity based on the condition, peculiarity and high regional potential.

This research will show the content of paragraph 11 about regional authority upon compulsory affair namely public service. Concerning with public service, it will not separate from the utilization of technology in implementing public service. The utilization of technology has been increasing in government especially in regional government. Therefore, a region might produce a governmental innovation as a strategy 
in public service. Regional government through innovation in the law number 23 of 2014 about regional government. In the chapter XXI about regional innovation, from paragraph 386 to 390 , explains that to increase the work of implementation of regional government is conducting innovation. Innovation is a renewal in implementing regional government. In formulating innovation policies, regional government refers to these following principles; efficiency improvement; effectiveness repair; service quality repair; no interest conflict; oriented to public interest; conducted openly; filling the value of suitability, and being able to be used for public interest. The utilization of technology to produce an innovation in regional government absolutely has a reason. It can be seen through the rapid population growth which emerges various problems in regional government especially in the city. The problems can be; the decrease of public service quality, the deficiency of residential land availability, the traffic jam, the difficulty in finding parking area, the increase of energy consumption level, the garbage accumulation, the increase of criminal rate and other social problems. Nowadays, the need of information can be easily accessed. Besides that, it is also fast, precise and accurate. Therefore, it becomes one of the basic developments in utilizing the information technology in government environment. The need of information has become one of the main needs because the government has tasks and responsibilities to the public service. The growth of population and the limitation of natural resource make the city management become more complex. This condition demands the government to maximize the resource potential and minimize any troubles and problems. The concept of smart city has become a big issue in big cities around the world which encourages the active role and participation of society in managing the city using the approach of citizen centric. It is aimed to create a more dynamic and closer interaction between the society and service provider (regional government). Two direction interactions will continuously develop to create a city as a comfort place to live and has integrity to quickly respond the change and new challenge.

According to Nam \& Pardo, the meaning of smart is; (1) in the sector of city planning, smart is meant as strategic, especially in selecting priority, direction, policy, and etc and (2) related to technology, smart contains the principle of automatic computation (self-configuration, self healing, selfprotection, self-optimization); it shows sensors and actuators. Furthermore, smart city is simply defined as a city which has management system to automatically inform that (1) the problem is happening (informed by the sensor installed in the city), (2) the problem will happen in the city (informed by sensor and prediction system) and (3) system of city management can provide the suggestion of automatic action (possibly conducted by system of actuator) or non-automatic action to solve the problems. Carragliu states that city will be smart if the investment of human resource, social modal, traditional and modern communication system infrastructure can improve the continuous economy growth and quality life by managing natural resource wisely through participative government management. Besides that, Cohen [2] divides smart city into six dimensions; (1) Smart economy;(2) Smart mobility; (3) Smart environment; (4) Smart people; (5) Smart living; dan (6) Smart governance, in which each dimension is elaborated into several indicators as presented in picture 1.1 Djunaedi (2014) adds one more dimension related to smart city, namely smart disaster management related to the location of Indonesia which is situated in the ring of fire.

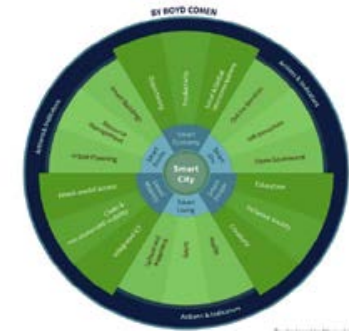

Fig. 1. Dimensions of Smart City. Source: [2]

Awaludin [3] strengthens the dimensions from Cohen on the criteria of smart city. There are 8 main parameters to determine a city which belongs to the category of smart city.

TABLE I. CATEGORY INDICATORS OF SMART CITY

\begin{tabular}{|c|c|}
\hline No & Category indicators of smart city \\
\hline 1 & $\begin{array}{l}\text { Smart Energy (the fulfillment of storage system and the use of } \\
\text { energy source efficiently) }\end{array}$ \\
\hline 2 & $\begin{array}{l}\text { Smart Building (the implementation of smart building } \\
\text { management and energy saving/ green building, automatic } \\
\text { system and the use of advance HVAC (Heating Ventilation \& } \\
\text { Air Conditioning)). }\end{array}$ \\
\hline 3 & $\begin{array}{l}\text { Smart Mobility (the use of sophisticated traffic management } \\
\text { system, parking management, and multi-model transportation) }\end{array}$ \\
\hline 4 & $\begin{array}{l}\text { Smart Technology (the implementation of seamless connectivity } \\
\text { such as } 4 \mathrm{G} \text {, wi-fi, super broadband, 1Gbps download, } \\
\text { Augmented Reality, LBS, and GPS. }\end{array}$ \\
\hline 5 & $\begin{array}{l}\text { Smart Infrastructure (the use of sensor management integrated } \\
\text { with smart governance and education, the formation of system } \\
\text { of } e \text {-Goverment, e-Education and solution of disaster } \\
\text { management) }\end{array}$ \\
\hline 6 & $\begin{array}{l}\text { Smart Healthcare (the availability of } e \text {-Health, } m \text {-Health and } \\
\text { smart and connected medical equipment) }\end{array}$ \\
\hline 7 & $\begin{array}{l}\text { Smart Citizen (the emergence of awareness to do a new habit } \\
\text { and culture which relates to the transportation system of go } \\
\text { green to apply healthy lifestyle). }\end{array}$ \\
\hline 8 & $\begin{array}{l}\text { Smart Security (the implementation of supervision guarantee, } \\
\text { biometric, preventive model to handle any kind of crime and } \\
\text { disaster anticipation) }\end{array}$ \\
\hline
\end{tabular}

Smart city becomes one of innovations which mostly built in Indonesia as a step of modernization and technology adoption into a broader sector. Jakarta, Makassar, Bandung and Yogyakarta are the examples of cities which implement the concept of smart city [4]. Smart city is a concept which has integrated connection in various sectors and gives practical impact and efficiency in city management. For example, Telkom cooperates with Bandung government to create Bandung Smart City. Concept of smart city emerges because of 
the dramatic reshuffle of the number of population in the city which encourages the society, city planner, business doers, and government to recognize a new vision of smart city. The right definition of the concept of smart city is actually various [4]. Smart city has been known in Indonesia and overseas. There are several cities which have implemented the concept of smart city such as Seoul, New York, Tokyo, Shanghai, Singapore, Amsterdam, London, Kairo, Dubai, Kochi and Malaga. It is not easy to implement smart city. It needs a strategic and creative mind. Strategic means that it is conducted based on the plan for the future (futuristic), start from problem identification, problem grouping, abstraction process, method determination, problem solution and implementation planning. Creative means a skill to produce a new and useful work in individual or organizational sector [5]. This research is aimed to know how the government implements an innovation policy of smart city. This research focuses on the challenge and obstacles faced by the government which has implemented smart city. The research observes the challenges and obstacles of the best practice in Indonesia.

\section{THEORY}

The concept of smart city is very popular. It is developed as a concept of city management around the world since several years ago as the technology has been developing rapidly. This concept has appeared since 1990s in which the internet connection was introduced in 1960s. According to Allwinkle \& Cruickshank [6], the internet development in that year has made the service easier with the accessible information through the sites provided by the government. Although it was still limited with one direction service and static information about policy of city, land use and planning, it was known as the factor of creating concept of smart city.

In the early 2000s, the development of information technology was rapidly developing since it made the users easy to communicate in two directions with real time from the different places. It was also easier with the adequate infrastructure. The information from the government was more interactive, accessible from anywhere and anytime. The database was more complete such as transportation, land use, planning, taxing and etc. The citizens do not need to come to the office government to see the current information from the policy stakeholder about the plan for the land around them. In 20014 and 2005, concept of intelcities also developed integrated system in all city service with online method and based on the sites on the internet. In that year, it also developed the transfer of knowledge and building the capacity through social network. It also empowered the society with online and integrated service. The development of intelcities is closely related to the popularity of social media such as friendster and facebook which makes the citizens easy to know each other. From 2015 until now, the development of intelcities shifted into smart cities by emphasizing the next level of intelcities such as being smart in a meeting, network, innovation, creativity, modernity, inclusive, and social modal as the last realization of continuous community.

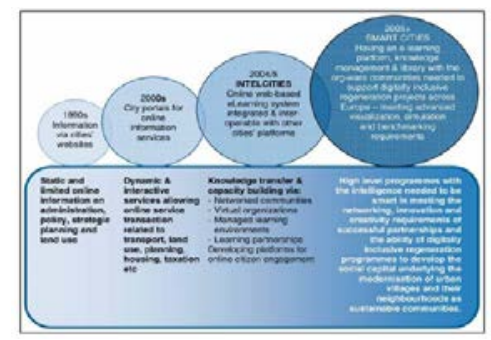

Fig. 2. Step of digital technology development in smart city. Source: Deakin and Allwinkle.

From the development mentioned by Allwinkle and Cruickshank above shows that the development of technology becomes one of the important things in the development of smart city concept. Nam and Pardo [7] explains that technology is not the only factors in smart city. There are two other factors, namely institutional and human factor as the supporter of the growth of smart city concept. The view of Nam and Pardo is mostly used by the city government, city manager and other sides that involve in developing the concept of smart city and implementing it in other cities in Indonesia.

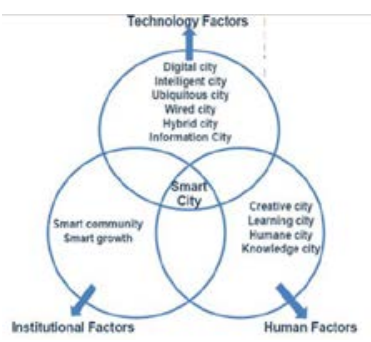

Fig. 3. Factor of smart city development

From the two perspectives above, the definition of smart city is more various as mentioned by several experts in the table below;

TABLE II. DEFINITIONS OF SMART CITIES

\begin{tabular}{|l|l|l|}
\hline No & According to; & Definition \\
\hline 1 & Griffinger et al [8] & $\begin{array}{l}\text { A city well performing in a forward-looking } \\
\text { way in these six characteristics (economy, } \\
\text { people, governance, mobility, environment, } \\
\text { and living) built on the smart combination } \\
\text { of endowments and activities of self- } \\
\text { decisive, independent and aware citizens. }\end{array}$ \\
\hline 2 & Kourtit \& Nijkamp [9] & $\begin{array}{l}\text { Smart city is a result of intensive knowledge } \\
\text { development and creative strategy in } \\
\text { improving the quality of social-economy, } \\
\text { ecology, and city competitive effort. The } \\
\text { emergence of smart city is a result of } \\
\text { combination modal of human resources (for } \\
\text { example; educated workforce), } \\
\text { infrastructure modal (for example; high } \\
\text { technological communication facility) and } \\
\text { entrepreneurial modal (for example; activity } \\
\text { of creative business). The strong and reliable } \\
\text { government and creative and open-minded } \\
\text { person will improve the local productivity } \\
\text { and accelerate the economy growth in a city. }\end{array}$ \\
\hline 3 & Yang [10] & $\begin{array}{l}\text { The city area creates continuous economy } \\
\text { building and high life quality for the society } \\
\text { by improving six main things such as }\end{array}$ \\
\hline & &
\end{tabular}




\begin{tabular}{|c|c|c|}
\hline & & $\begin{array}{l}\text { government, economy, life quality, } \\
\text { environment, human resource and } \\
\text { transportation which can be conducted } \\
\text { through information technology } \\
\text { infrastructure and strong communication. }\end{array}$ \\
\hline 4 & Chourabi et al [11] & $\begin{array}{l}\text { "A city that monitors and integrates } \\
\text { conditions of all of its critical } \\
\text { infrastructures, including roads, bridges, } \\
\text { tunnels, rails, subways, airports, seaports, } \\
\text { communications, water, power, even major } \\
\text { buildings, can better optimize its resources, } \\
\text { plan its preventive maintenance activities, } \\
\text { and monitor security aspects while } \\
\text { maximizing services to its citizens.” }\end{array}$ \\
\hline 5 & Cohen Boyd [2] & $\begin{array}{l}\text { Smart city is a broad and integrated } \\
\text { approach in improving the efficiency of city } \\
\text { operation, life quality and regional economy. } \\
\text { Cohen defines smart city with the aspect of } \\
\text { environment; smart city uses ICT efficiently } \\
\text { by using various resources, produces fee and } \\
\text { energy saving, improves the service and life } \\
\text { quality, and reduces environment tracks- all } \\
\text { of them support the innovation and economy } \\
\text { of friendly environment. }\end{array}$ \\
\hline 6 & $\begin{array}{l}\text { Ahmad Nurman in } \\
\text { city management }\end{array}$ & $\begin{array}{l}\text { Smart city is generally based on the three } \\
\text { things. Firstly, human factor, city with } \\
\text { creative human in the work, knowledge } \\
\text { network, and free criminal environment. } \\
\text { Secondly, technology factor, a city based on } \\
\text { the technology, communication, and } \\
\text { information. Lastly, institutional factor, } \\
\text { urban society (government, business person, } \\
\text { and citizens) that understands the } \\
\text { information technology and makes the } \\
\text { decision based on the information } \\
\text { technology. }\end{array}$ \\
\hline
\end{tabular}

Although the definition of smart city in the table is various, it shows several similarities that the implementation of smart city in city planning is to realize the continuous building by improving public service and integrating several elements in the city such as government, economy, life quality, environment, human resource and transportation.

\section{DimENSIONS OF SMART CiTY}

[8, p. 10-14] explains six dimensions in the concept of smart city as the basis of smart city implementation. Then, it is used to count index of smart city in 70 cities in Europe. The six dimensions and its indicators can be seen in the picture below;

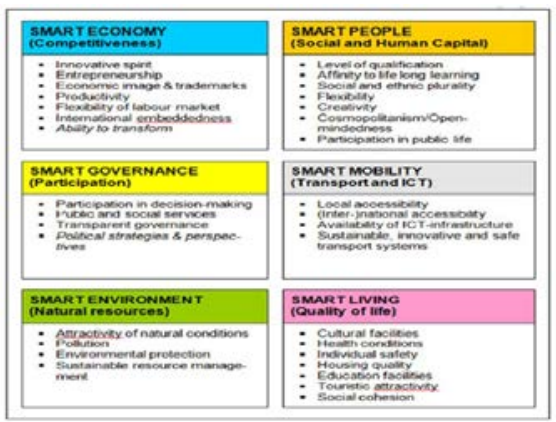

Fig. 4. Dimension of Smart City. Source: [8].

\section{RESEARCH METHOD}

Research method used in this research is descriptive method. According to Sugiyono [12], method of descriptive research is;

"Descriptive research is a research conducted to know the value of independent variable which can be one or more variables (independent) without making comparison or relating among the variables.” [12, p. 11].

Technique of collecting data in this research was library research. Collecting data was conducted through learning several literary books and documents related to smart city. In this qualitative research, data analysis was focused on the field process with collecting data. In the technique of collecting data, the researcher used the technique from Miles and Huberman. Data analysis consisted of three step activities; data reduction, data presentation. Data in reduction was presented based on the thought, opinion intuition or certain criteria to be placed in each category. According to Miles and Huberman, the most used step to present data in qualitative research was narrative text. At last, it was concluded and verified.

\section{DisCUSSIONS}

The development of technology becomes an attention in various sectors. Government becomes one of the sectors which utilize the development of technology. The use of technology is implemented by the government because of some reasons. Many problems happen and need solution. The problems are various such as in giving service and corruption conducted by the bureaucrat. The implementation of regional autonomy becomes one of the strategies of central government in managing region independence. Autonomy is not separated from a regional government. City becomes one of regional governments that have many problems such as the high population which moves to the city to search for a life. The rapid growth of population creates various problems such as the decrease of public service quality, the deficiency of residential land availability, the traffic jam, the difficulty in finding parking area, the increase of energy consumption level, the garbage accumulation, the increase of criminal rate and other social problems. In 2045, it is predicted that $82,37 \%$ of Indonesian will live in the city. Therefore, it needs a concept of smart city that can give a proper place for the citizens and improve the efficiency of public service. Smart city is a concept of city development by implementing the advance of technology to enable the interaction between the government and its citizens. According to Nam \& Pardo, the meaning of smart is; (1) in the sector of city planning, smart is meant as strategic, especially in selecting priority, direction, policy, and etc. and (2) related to technology, smart contains the principle of automatic computation (self-configuration, self-healing, selfprotection, self-optimization); it shows sensors and actuators. [2], [8]-[11] also state that the concept of smart city is a solution through synergizing technology, human being, and environment. Therefore, the concept of smart city has been developed and implemented in several cities in Indonesia.

To utilize the potential effectively, one of the strategies conducted by the government is through "Gerakan Menuju 1000 Smart City" (a movement toward 1000 smart cities). 
There has been 25 cities and regencies as the pioneer of smart city of Indonesia 201 such as; Jambi, Pelalawan, Siak, Banyuasin, Tangerang, Tangerang Selatan, Purwaarta, Bandung, Bekasi, Bogor, Cirebon, Sukabumi, Sleman, Semarang, Banyuwangi, Bojonegoro, Gresik, Sidoarjo, Badung, Singkawang, Kutai Kartanegara, Samarinda, Makassar, Tomohon, and Mimika [13]. Several cities above become a proof that the city in Indonesia has a potential to become smart city. The city government in Indonesia has a strategy to develop smart city. The development focus conducted by the government is providing media and infrastructure, improving economy media, developing the city safety based on technology of information and communication, improving health service, education and social-culture, providing proper and affordable place and developing system of public transportation which is integrated with city typology and geographical condition. Planning of smart city is expected to help the city solution such as the existence of public transparency and participation, public transportation, non-cash transaction, management of waste, energy, security, data and information [14]. The development of technology becomes the basis of smart city. According to [6], the development of technology encouraged the emergence of smart city from 1990 until 2005. Technology was used by the government to deliver the information. In 2005, it became the basis of smart city. According to Pardo, technology is not the only factor in smart city. [7] states that there are 2 other factors such as institutional and human factors as the supporter of the growth and development of smart city. Although there are many solution descriptions offered by smart city, it needs to pay attention to the obstacles and challenges in the implementation of this new concept. This research wants to observe the obstacles and challenges of the implementation of smart city in several cities in Indonesia. The researcher selected three cities such as Jakarta, Bandung, and Surabaya. The selection was based on the scientific journal from several journal searching machines.

The research from Tampubolon [15] concluded that the realization of smart city in Jakarta (smart Gov, smart people, smart mobility, smart economy, smart living dan smart environment) used the technology of information in Indonesia especially Jakarta which has ecosystem determined by ministry of communication and information (network, device dan application). The utilization of information technology gave positive impacts toward the work of the government in realizing smart city in Jakarta. It was proven through the assessment of PeGI in which the assessment of Jakarta always belonged to good category and tended to increase in the period of 2012-2015. The achievement increased from the third position to the first one in 2 years. In this research, the most used application is Waze, defeated Qlue which functioned to deliver complain to the government. It indicated that traffic jam in Jakarta needed to fix. Furthermore, the management of information and technology (smart governance) also needed to improve. The handling of traffic jam (smart mobility) and other big problems like waste must be fix rapidly to realize smart city. Another research was from Ely Yani [16] which concluded that the obstacles of smart city was the implementation of Qlue that made the side of neighborhood association negatively asses the regulation of Qlue adoption. The regulation might create conflicts between society and neighborhood association. Another obstacle was the society factor or human resource that involved in the implementation of smart city in Jakarta. It was strengthened by the research from [17] that the availability of public space service in city park (Menteng park) based on technology of communication and information was still limited on the provision of service and infrastructure such as internet network with stream media of wi-fi (wireless fidelity) which needed authentication to access the network of wi-fi. The shortage of the service availability based on technology of information and communication is caused by the focus of government and provider on the supplying the network access. Another factor is maintenance of media of technology of communication and information. It must be handled by the expert as the anticipation of the security in the network. The utilization of public space in Menteng Park is still limited on the use of internet through wi-fi. The users are the visitors of the park who come to access the current information through online media, social network, article, and online entertainment multimedia. There are also other uses such as e-banking, epayment, and e-shopping. The use is still low because the internet network is not adequate and stable to do the safe transaction. Lastly, the research from Lail, Lutfianah [18] concluded that there were many obstacles. The document had not been arranged well and the concern of the society was still low in which it obstructed the policy of smart city. The successful implementation of the smart city was the leadership factor of the governor who directly supervised the implementation of the policy. Therefore, the policy must be strengthened with supporting factor such as leadership and solution to fix the planning document and society concern. Widyaningsih [19] in implementing smart city in Surabaya, the government work must be fixed first because government is the building media. If the government cannot work well, the programs will not be optimal. The development of smart city cannot be started with sophisticated technology without any social approach. If the development of smart city does not use social approach, and only focuses on the development of high technology, there will raise urban splintering, useless technology and make the people find the difficulty. Mursalim concluded that the implementation of smart city in the agency of communication and information of Bandung government has not been socialized and communicated well to the SKPD or other agencies. Therefore, many residents have not known about smart city. In socializing the program of smart city, it needs a long process and must be supported by the government and its citizens. To support smart city, the citizens must also be smart people. It was difficult to create smart people, so the governor, Mr. Ridwan Kamil proposed to implement smart government. If the smart government is successful to implement smart city, the citizens would also be smart people. Based on the above findings, the difficulty in implementing smart city is on the sector of technology and human resources. According to the dimension from [8], obstacles and challenges faced by the government of Jakarta, Surabaya and Bandung is technology, smart governance, and smart people. This problem must be solved by the government to realize the implementation of smart city as a new concept to solve the city problems. 


\section{CONCLUSION}

There are many sides that attempt to create smart city. However, there are many challenges to realize the concepts in Indonesia. One of the challenges is the high price of equipment and it is difficult to find it. Not all areas in Indonesia have adequate infrastructure to support the utilization of IoT. According to Fanky Christian from association of integrator system and security of Indonesia, regional government needs to provide infrastructure of information technology as the first step to realize smart city. If the infrastructure has been adequate, each region can make data center or command center. Another challenge is preparing the society to accept the digitalization change. It has been delivered by the representative of city government that the aim of smart city is to make the public service easier. Therefore, if the side of government has provided the service based on the information technology, the public must be ready to use it and the service can be maximum. The ministry of communication and information has delivered their commitment to support the development of smart city in Indonesia. The central government has ever planned the program of 100 smart cities as the cooperated program of the ministry of communication and information, ministry of domestic affair, ministry of public work, national development planning agency, and office of presidential staff. The minister of communication and information, Rudiantara, states that there are 514 regencies/ cities in Indonesia. Therefore, the development of smart city must consider the fund estimation whether it can survive to fill the need of budget in building smart city. The program of 100 smart cities has been implemented by the regional government by preparing various infrastructures of information technology, human resources and regulations to rule the policy.

\section{REFERENCES}

[1] S. D. Salam, Manajemen Pemerintahan Indonesia [Indonesian Government's Management]. Jakarta: Djambatan, 2007.

[2] B. Cohen, "The smartest cities in the world 2015," 2013. [Online] Available: https://www.fastcompany.com/3038818/the-smartest-citiesin-the-world-2015-methodology. [Accessed Apr. 24, 2018].

[3] M. Awaluddin, "Katalog smart city solution [Smart City Solution Catalogue],” Telkom Solution, 2016. [Online]. Available: www.telkomsolution.com/themes/v2/catalogue/Katalog\%20Smart\%20C ity\%20v4.pdf.

[4] Syahbudin, "Analisis penerapan smart city dan internet of things (IoT) di Indonesia [Analysis of Smart City and Internet of Things (IoT) Implementation in Indonesia],” academia.edu, 2015. [Online]. Available:
http://www.academia.edu/15371881/Analisis_penerapan_smart_city_da n_internet_of_thing_(iot)_di_indonesia.

[5] M. A. Schilling, Strategic Management of Technological Innovation (A. L. Lazuardi and A. Lintang, Transl.). Yogyakarta: Penerbit Pustaka Pelajar, 2015.

[6] S. Allwinkle and P. Cruickshank, "Creating Smart-er Cities: An Overview,” J. of Urb. Technol., vol. 18, no. 2, pp. 1-16, April 2011.

[7] T. Nam and T. A. Pardo, "Conceptualizing smart city with dimensions of technology, people, and institutions," in Proceedings of the 12th Annual International Digital Government Research Conference on Digital Government Innovation in Challenging Times - dg.o '11, 2011, p. 282.

[8] R. Giffinger, C. Fertner, H. Kramar, and E. Meijers, Smart cities Ranking of European medium-sized cities. Final report, October 2007.

[9] K. Kourtit and P. Nijkamp, "Smart cities in the innovation age," The Eur. J. of Soc. Sci. Res., vol. 25, pp. 93-95, June 2012

[10] J. H. Yang, Smart City Smart Strategy. KC Smart Service, 2012.

[11] H. Chourabi, et. al., "Understanding Smart Cities: An Integrative Framework,” 45th Hawaii International Conference on System Sciences, 2012.

[12] Sugiyono, Metode Penelitian Kuantitatif, Kualitatif dan R \& D [Quantitative, Qualitative, and R \& D Research Method]. Bandung: Alfabeta, 2007.

[13] A. H. Haryanto, “Ini 50 Calon Smart City di Indonesia, Salah Satunya Depok [This is 50 Candidates of Smart City in Indonesia, One of them is Depok]," detikInet, May 8, 2018. [Online]. Available: https://inet.detik.com/cyberlife/d-4011124/ini-50-calon-smart-city-diindonesia-salah-satunya-depok.

[14] D. Setiaji, “Apa Itu Smart City dan Tantangan Penerapannya d Indonesia [What is Smart City and its Challenges on Implementation in Indonesia]," Techinasia, May 14, 2018. [Online]. Available: https://id.techinasia.com/apa-itu-smart-city-dan-penerapan-di-indonesia.

[15] L. P. D. Tampubolon, "Pemeringkatan E-Government Indonesia (PeGI) dan Pemanfaatan Teknologi Informasi di DKI Jakarta [Indonesia's EGovernment Ranking (PeGI) and Utilization of Information Technology in Jakarta Special Capital Region],” Jurn. Sist. Inform. (JSI), vol. 8, no. 2, October 2016.

[16] E. Yani, “Analisis Relasi Teknologi, Institusi, dan Agensi dalam Transformasi Pelayanan Publik di Jakarta [Analysis of Technology, Institution, and Agency Relationship in Public Service Transformation in Jakarta],” Inform. Kaj. Ilmu Komun., vol. 47, no. 1., June 2017.

[17] R. H. Saragih and R. Rachmawati, "Penyediaan Ruang Publik Taman Kota Berbasis Teknologi Informasi dan Komunikasi dalam Mendukung Jakarta Smart City di Taman Menteng, Jakarta Pusat [Information Technology and Communication-based Public Space City Park Provision to Support Jakarta Smart City at Menteng Park, Central Jakarta],” Jurnal Bumi Indonesia, vol. 4, no. 3, 2015.

[18] L. Lail, "Implementasi Kebijakan Smart City di Provinsi Daerah Khusus Ibukota Jakarta [Implementation of Smart City in the Province of Jakarta Special Capital Region],” Bachelor thesis, Brawijaya Univ., 2017.

[19] D. Widyaningsih, "Kota Surabaya Menuju Smart City [Surabaya City towards Smart City],” Thesis, Gadjah Mada Univ., 2013. 